\title{
CDKN1B wt Allele
}

National Cancer Institute

\section{Source}

National Cancer Institute. CDKN1B wt Allele. NCI Thesaurus. Code C49509.

Human CDKN1B wild-type allele is located within 12p13.1-p12 and is approximately $5 \mathrm{~kb}$ in length. This allele, which encodes cyclin-dependent kinase inhibitor 1B protein, plays a role in the progression of the cell cycle at the G1 phase. 